\title{
Language Laboratory to Overcome the Barrier of Classroom English Learning: Does it Exist and Is it Used in Islamic Schools of Majene?
}

\author{
Nur Fadillah Nurchalis ${ }^{1}$, Ermawati Ermawati ${ }^{2}$, Ahmed Sardi ${ }^{3}$, and Nursabra Nursabra ${ }^{4}$ \\ ${ }^{1,4}$ Sekolah Tinggi Agama Islam Negeri Majene, Majene, Indonesia \\ ${ }^{2}$ Institut Agama Islam Negeri Palopo, Palopo, Indonesia \\ ${ }^{3}$ Institut Agama Islam Negeri Parepare, Parepare, Indonesia \\ nurfadillahnurchalis@stainmajene.ac.id
}

\section{ARTICLE HISTORY \\ Received : 21 May 2021 \\ Revised : 9 July 2021 \\ Accepted : 9 October 2021}

\section{KEYWORDS}

English

English Teachers

Islamic Schools

Practical Activities

Language Laboratory

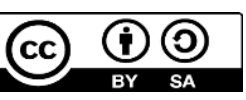

\begin{abstract}
A staple issue in English language teaching is the fact that individual students in formal classrooms usually have minimal opportunity to speak due to large class sizes. Recent studies have vouched language laboratories to be capable of overcoming this barrier. As far as the researchers know, no study has launched a wide investigation whether a language laboratory exists and is used to optimise the English learning in the Islamic schools in Majene, Indonesia. This research applies descriptive quantitative design, involving 22 Islamic schools in the level of junior high school. 22 English teachers that represents all the schools filled a questionnaire to provide the data. It is found that the Islamic schools at Majene do not yet have a language laboratory even though the English teachers consider it important. Its absence is influenced by the lack of support from leaders. As a result, listening practice activities are rarely carried out. English teachers only carry out practical activities in the classroom with limited tools and materials. This research illuminates a concern for policy makers in the Ministry of Religious Affairs in the field of Islamic school education and the principals to hold a language laboratory at Islamic Schools. To improve English learning activities, the existence of a language laboratory in Islamic schools is matter, so that students at Islamic schools can show their quality in foreign language mastery and compete with others.
\end{abstract}

\section{Introduction}

Even having learnt English for many years, English language learners still undergo some barriers in speaking English. Some learners get confused when someone asks them in English, and some of them are afraid of making mistakes to respond questions or statements. It is due to lack of practice during the lesson (Abdelaziz, 2017). Most learners only practice their English in the classroom because there they can find partner to communicate (Zaim, 2017). People used to learn English because they wanted to study literature written in English, but now people mainly learn English to communicate in the target language (Rao \&Velagala, 2016). What teachers should do is providing and creating opportunities for learners to communicate in English as much as possible. Communication includes learners' ability to catch the meaning of what they listen and respond it in turn.

Class size can affect learners' opportunities in practicing English (Bosco et al., 2020). In an average foreign-language class, all language learners speak only $23,5 \%$ of the class time (Desi, 2006). Other 76,5\% learners have to wait until the next meeting to practice speaking. If there are 10 students in the classroom, it means that there are only 2-3 learners who have chance to practice speaking. In fact, teachers should handle 20-30 learners in language classroom during 90 minutes. It means every learner has only around 2-3 minutes to practice whereas every learner needs more time to think and choose what words they want to express when they speak. In addition, many students state that their speaking performance is influenced by time allowed to perform (Tuan \& Mai, 2015). Speaking practice in few minutes cannot assure development of language communication skills.

A recent consensus among educators and researchers alike is that a language laboratory can be expected to overcome those barriers. Language laboratory has wide variation of possible feedback mechanisms (Khaleel, 2020). It also creates better interaction and attentions (Vishalakshi, 2011). This indicates that the interaction that can be created when learning English in the classroom is more limited. Also, it helps teacher listen and care about the students without being detected with the help of facilities (Obiageli \& Ogochukwu, 2017). Language laboratory offers many kinds of activities to apply. Teachers can manage communication in various directions, such as monologue, dialogue, and doing group discussion in sufficient time without distracting each other. Joan and Mabel proved that students achieved better in a language learning when they learnt in a language laboratory than in a classroom (Joan, 2016).

Language laboratory also helps learners who are shy to perform in front of the class. It overcomes learners' shyness by providing private activity in the use of headset and microphone (Kin-Sys, 2007). It intends to keep his/her 
privacy. Language Laboratory is not only designed for inclass activities, but also self-study. It aims to increase practice time even after the class ends. For instance, learners will record themselves and compare the way they speak with native speakers, so they can identify their mistakes. Those kinds of treatments will improve learners' confidence to communicate. Language laboratory has potency to accelerate learning process (Blanco-Elorrieta \& Pylkkänen, 2017; Nonci et al., 2018).

A laboratory is great. It provides learners relaxation, exposure to authentic learning, confidence, individuality, interactions, and immediate feedbacks. It is best place to practice listening and speaking, but not for reading and writing. Teachers' creativity, up to date knowledge, and selection of software decide the attainment. A well-adjusted approach will make language laboratory a perfect strategy in the long-term success of the language learning process (Chandradasa \& Jayawardane, 2018; Cosmas, 2020). It shows the strategic position of a language laboratory at schools.

Nevertheless, a number of language laboratories only become accessories. Many of them are not functioning properly. Majority teachers are not trained well to use lab equipment (Kurniawa, 2014). They teach at language laboratory room, but they apply traditional ways to teach speaking as they do in traditional classroom. Language laboratory is not limited to a set of machine and equipment in a room physically, but it is rather than digital technologies that enable learning experiences (Kampushaen, 2013). On other hand, the language laboratory is positively disposed since the use of online learning is readily available to be used (Adamu et al., 2018). The main point of teaching in language lab is participation of all learners to hone their listening and speaking skills with technology supports (Ermawati \& Umar, 2020; Khalil \& Ibnian, 2020).

Islamic Schools, as schools under control of Religious affairs ministry, has the motto "-Islamic schools are better and better to choose Islamic schools," (Kemenag, 2014). Through this motto, Islamic schools initiate to show their excellence in which the students can learn both general and Islamic science at once. Islamic schools promote integration of religious and general knowledge as their value. Islamic schools' students are expected to be able to master foreign languages such as Arabic and English. Islamic schools' students are demanded to have special quality. Therefore, foreign language skill improvement becomes an important matter.

To achieve a very good progress in English, the use language lab is offered as way to foster students' language skills. In a language laboratory, students' participation increases. The learning proses is also more interesting (Krishna, 2021). The interest in doing this research stemmed from anxiety over the limited opportunities for practicing English in the classroom. This study is a part of an attempt to fill the gap in the lack of time for these opportunities due to the large number of students in the classroom becomes very important when compared to the number of benefits offered by the language laboratory as contained in the literature. Investigation of the existence of a language laboratory to overcome language learning barriers due to the large number of students in the classroom has not been the concern of previous researchers. Therefore, this study aims to investigate the existence of language laboratories in Islamic schools in the level of junior high schools of Majene to overcome language learning barriers due to the large number of students in the classroom.

\section{Literature Review}

Language laboratory is an audio-visual installation used in modern teaching methods to learn the foreign languages (Deepika \& Kalairasan, 2012). Language laboratory is a specific room in which foreign language instruction can be enhanced through activities, or training. It is designed exclusively for learners to learn theory and practice the language lesson (Stack, 1971). These two definitions limits language laboratory as a room facilitated with modern machines.

Cesteros (2014) describes language laboratory more broadly. Language laboratory is much more than a tool for training, drilling and listening discursive language. It is a place to learn and experiment with real samples of languages, learn languages and exercise in its use. Language laboratory is modification of multimedia technology and language instructional materials that stimulates learners' multisensory. It intends to build up communication practices which are adaptable. This innovation has been recognised as an enjoyable learning tool that closes to students' real life (Evan, 2009). These definitions emphasise that language laboratory is not only a room with completed hardware, but also about various software available to support many kinds of communication practices. The main purposes of language laboratory are to make individual practices of learners more effective, and increase productivity of language learners (Navas, 2013).

Furthermore, English laboratory is a powerful tool with which students can acquire the target language in a low anxiety setting and interesting, rich and comprehensive input (Chandradasa \& Jayawardane, 2018). Mercy emphasises that language laboratory is convenient for both low and high language achievers and can solve many language problems (Mercy, 2016). Language laboratory offers solutions for a number of obstacles in language learning. Its usage is vital (Obiageli \& Ogochukwu, 2017).

In Adamu \& Umar's research (2018), they discuss about students' opinion about advantages of the use language lab in their learning. That research found that students who learnt in the language laboratory could realise the correct pitch better than other students who learnt in the classroom. It indicates a positive role of language laboratory to improve students' pronunciation. 
The same as Adamu et al.'s findings, Sihite (2017) also found that learning English in language laboratory works effectively for students. It happened because language laboratory applies technology integration. It offers variety of interactions which provide lots of opportunities for students to practice. Considering that good prospect of using language laboratory in learning a foreign language, it also is important to know any significant obstacles in practicum activities faced by students at school. Therefore, this research concerns on identifying barriers encountered by English Teachers on English learning practicum at language laboratory at Islamic Schools in Majene. There are two important things to consider in this area:

\subsection{Kinds of Language Laboratory}

Language laboratory has developed rapidly over the years. It helps teachers provide foreign language lesson. Aleman categorises four kinds of language laboratory (Mercy, 2016). There are:

\subsubsection{Conventional Laboratory}

It is the earlier form of language laboratory. It is equipped with very simple tools such as tape recorders and audiocassettes of target language to teach. Conventional language laboratory used tape recorder to replace human element (Allen, 1974). It was because human had limitation energy to do drilling in the classroom, while tape recorder was indefatigable. Teachers operate it in conventional ways in which teachers turn on the cassette player and the learners listen to it. After that, learners will imitate the way to pronounce it. It does not have specific difference with language learning conducted in the traditional classroom which completed by several aids. Distraction among learners potentially happens. The use of the lab is incorporated with pedagogical framework, support form learners, and interaction between tutor and students (Alkhaldi et al., 2016). This is no longer common. Its presence helped pronunciation improvement among students (Adamu et al., 2018). This kind of language laboratory is no longer used.

\subsubsection{Lingua Phone Laboratory}

It is similar to conventional laboratory, but it is more modern. This lab provides headsets for students to listen the cassette played by the teacher. This additional aid reduces distraction among learners. Learners also can listen the cassette clearly because headset makes students more focus (Sihite, 2017). Another modern lingua phone laboratory uses an electronic device which has dual functions. It is used to play the cassette, and also repeat the recording. Learners can use this to compare the recorded voice and native speakers' voice from audio cassette. Also, it functions as normal cassette and as repeater to help record and to play back in comparison (Matthew, 2020). It is an improvement of conventional language laboratory. It promoted autonomous learning (Asri et al., 2016).

\subsubsection{Computer Assisted Language Laboratory (CALL)}

This type of laboratory uses computer for language instructions. The language teaching materials are available in the computer. This is one of the well-known speech laboratories which all courses are already stored in it (Matthew, 2020). It contains some features to assist teachers selecting suitable activity to perform. CALL continuous to grow over time. These days, the computer is also equipped with internet connection, so both teachers and learners can explore various learning activities in websites. Such thing is called Web Assisted Language Laboratories (WALL). CALL which develops gradually is categorised into three stages. They are behaviouristic CALL, communicative CALL, and integrative CALL (Barson \& Debski, 1996). Also, CALL laboratory simply let students interact with teachers in systematically computerized system (Asningtias, 2018).

The programs of behaviouristic CALL emphasises on language repetition. It was believed that the more learners have drills, the faster learners speak foreign language fluently. The point is drills and practice. In its development, the communicative CALL was initiated by communicative approach well-known in the 1970s and 80s. It was assumed that drilling was not insufficient to create authentic communication patterns for students because all instructions still relied on the teachers while communication should be learners' initiation. Then, the integrative CALL combines two important technological developments of the last decade, namely multimedia computers and the Internet. In addition, CALL is not limited to teach communication skills only. CALL also works for teaching vocabulary and grammar (Khaleel, 2020).

\subsubsection{Multimedia Hi-Tech Language Laboratory}

Multimedia Hi-Tech Language Laboratory is combination the use of computer which contains variety of media such pictures, video, graphics, etc. and the use of online resources linked to computer. Multimedia Hi-Tech Language Lab becomes powerful since it requires hypermedia. Hypermedia gives lots of contributions for language learning. It facilitates comprehensive self-study, so that when teacher practice with half students in the room, another half can learn independently. Therefore, every student has enough chance to practice with the help of sophisticated tools (Kumar, 2017). Also, the laboratory makes students focus on the presented issue without taking any notes and teachers become more independent to use the availability of the laboratory (Borowska \& Enright, 2015). Furthermore, it provides lots of software available to use online that can be used in the multimedia language laboratory such as Aristoclass, Renet, Hiclass, etc. (Matthew, 2020).

There are four reasons why language laboratory are better used for language teaching (Sihite, 2017). They are first, it creates a more authentic learning environment like 
in the real word because it uses two sensory, namely listening and seeing. Student are able to listen and practice the language for more language acquisition (Abdulla \& Kumar, 2017). Secondly, skills are effortlessly integrated. Learners can improve their English skills at once because various media integrate listening, speaking, reading, and writing in one activity. Thirdly, learners are more discipline in learning because teachers have set communication activities like individual and group activities. They cannot set their own because teachers handle the master program. It is effective to hone on particular aspects and skip other aspects. Finally, a primary advantage of hypermedia is that it simplifies a principle focus on the content, without losing a secondary focus on language form or learning strategies. For instance, while the main lesson is in the foreground, students can have access to a variety of background links which will allow them rapid access to grammatical explanations or exercises, vocabulary glosses, pronunciation information, or questions or prompts which encourage them to adopt an appropriate learning strategy (Warschauer, 1996).

Some schools have a language laboratory, and some of the not. The kinds of language laboratory may vary. It depends on the principal's policy whether he or she save budget to run, or to renew or to update its hardware and software. Some schools have lots of budget, but the principal as policy maker does not put language laboratory as priority to upgrade (Aulia, 2016). Quality of language laboratory relies on principal's commitment to follow the development of modern technology. The more modern a technology, the more helpful it is. Each kind of language laboratory has their own obstacles and challenges for users (Sihite, 2017). In addition to the modern technology use, the management of language laboratory to support language use is challenging not only for school system, but also for teachers and students (Aulia, 2016).

\subsection{Factors Affecting Effectiveness of Language Laboratory}

Yeong \& Chiew (2014) mention the considered important factors affecting the effectiveness of language laboratory instruction system. They are:

\subsubsection{Human Elements or Users}

There are two regular users of language laboratory at schools. They are teachers or instructors, and learners or students. Both of them have different needs and responsibility when utilising the language laboratory. In addition to the language learning in language laboratory to become more effective, there are some things that teachers must pay attention to (Aulia, 2016; Sihite, 2017). They should know how to operate all tools available in the room, and all gadgets on the console panel and their familiarity to all tools. It is not only about turning on the machine or pushing or clicking buttons by reading the standard operating procedures, but they should know how to maneuver it to learning objectives. Teachers also have to know the programming techniques, for example how to introduce various activities to break repetitive drills which is monotone, how to encourage learners to participate with enthusiasm and how to evaluate learners' progress (Khaleel, 2020).

Teachers are one of the keys of English learning success in the laboratory. Teachers do not only bring benefits for themselves in using language laboratory equipment, but also bring benefits to students, especially the effectiveness and efficiency of their learning (Adamu \& Umar, 2018). Therefore, schools need to pay attention to their policy of sending their teachers to participate in language laboratory operation training. It is also necessary for learners to know certain things when they want to use language laboratory. They should learn how to use the entire gadget set up in the booth including headset and responding buttons (Sihite, 2017). They must dare to communicate with the communication patterns designed by the teacher. They have to follow instructions. They need to measure their achievement by considering learning objectives (Krishna, 2021).

\subsubsection{The Strategies}

There are some ways to utilise language laboratory. Here are systematic strategies for effective instruction (Sihite, 2017). An instruction should be managed based on its objectives. Like instructional process in traditional classrooms, activities in language laboratory should be developed by considering instructional objectives. Teachers should split the learnt skills into small units and provide instruments to measure whether the objectives have been achieved or not (Aulia, 2016). It is also support students to provide real exposure of usage of real life of English native speakers. The use is always the shift of traditional to be more supported learning environment, in this case is language laboratory (Asningtias, 2018; Krishna, 2021). Before giving a treatment, teachers should give pre-test to know learners' prior knowledge in the unit. It aims to map learners' performance and choose what treatment that is suitable for them. If the performance is higher than the standard level, the unit should be skipped, but if the performance is lower than the standard level, the unit should be taught. After giving treatment, a post-test should follow (Adamu et al., 2018; Sihite, 2017) Also, strategies in managing the use of language laboratory is to organise the activities planned in advanced. The activities are referred to activities which consider the safety, comfort, effectiveness and efficiency (Asningtias, 2018; Aulia, 2016; Matthew, 2020), Learners who pass the post-test could certainly continue to the next unit. On the other hand, the learners who do not pass the post-test should revise the previous unit. The administered tests avoid boredom to those who are more proficient. They do need to repeat many times what they have mastered. In contrast, for those who are less proficient, the lesson becomes challenging for them (Yeong \& Chiew, 2014). Managing this situation language laboratory is feasible because it provides multiple 
channels and response analysers sophisticatedly (Aulia, 2016; Krishna, 2021).

In addition to managing instructional objectives, utilisation of audio-visual aids prevents the boring activities for learners like the monotony drilling. Language laboratory should utilise novel learning tools. The use of multimedia teaching such as slides, film-strips, and music break the monotony. Patel highlights that the use of multimedia makes the class interesting, and lively enhancing the initiatives of both teachers and learners (Patel, 2013). The presented material by using audio-visual aids should provide content for discussion, practices and testing in which the aids serve freedom for learners to perform (Sahraini \& Syamsudarni, 2018). The strengthening activities in language laboratory also should be interesting; otherwise, it drives learners into tears. Teachers should maintain students' motivation to learn foreign languages. An entertaining activity really helps a lot. Teachers may give games or quizzes which are relevant to the instructional objectives. It also speeds up learners' understanding.

Berte in Buska et al. (2020) argued that the implementation of activities in a language laboratory relied on the coordination of both teachers and laboratory manager or technician. To optimise the needs of practice activities, the use of appropriate language laboratory equipment, materials and administration should be communicated among the ussers of a language laboratory.

\subsubsection{The Software}

Chapelle in Borges revealed that software and hardware have a strong attachment to language learning in language laboratories. Software has several advantages such as providing various native speaker models in different media; offering a language learning curriculum; doing need assessment; determining better treatment for students; recording students' activities and evaluation; and being available at any time (Borges, 2014).

Adequate and appropriate software such as lesson plan, programmed tapes and course-book let language laboratory instruction system work effectively and efficiently (Sihite, 2017). Lesson plan is the main point of instructional process. It covers the performance objectives, source of instruction materials, time allotment, and methods of instruction, instructional activities, and test items (Permendiknas No 41, 2007). It contributes to teachers' readiness to handle the class. It monitors the teachers not to do other activities that is irrelevant to objectives and takes time.

A tape used in language laboratory should contain learning materials, drill exercises, test items, and assignment for reinforcement for the teaching of target language (Adamu et al., 2018). If the tape contains nothing, the language laboratory will look like a bottle without water. It cannot heal thirst. The software in the electronic devices should be various, so that it increases teachers' creativity to modify and select suitable programs to apply in the class. It also stimulates learners' sensory such as eyes and ears to acquire the language easily and quickly (Patel, 2013). A tape-recorder allows students to record their sound to be used in teaching communicatively (Nonci et al., 2018).

In addition to software, soft file of course-book is also provided by publisher to help teachers a lot. It inspires teachers to perform teaching. It has been stored in computer and presented to students by using available features in the system (Sihite, 2017). However, teachers should develop it based on their students' needs. They can add, omit, mix, modify and substitute some parts. If the course-book is so easy for learners, it will not challenge them. In contrast, if the course-book is too difficult for the learners, it may kill their motivation. The need analysis is applied to identify the students' need in order to enable teachers to construct survey to identify the appropriate technological tools used in the language laboratory (Aulia, 2016).

\subsubsection{The Hardware}

The instruction system at language laboratory would be effective and efficient if the machines function properly. The more frequently a language laboratory is used, the bigger its possibility to broke. It happens because some learners deny the regulations of language laboratory usage, for example they pull some cables, they push some buttons harshly, and they ruin the headphone and microphones in the booth. The failure of machine affects interaction between teachers and learners. It is important to deals with regular maintenance to protect the language laboratory devices. The repair and recheck of the tools can possibly prevent them from possible damage situation (Aulia, 2016).

Afterwards, this turns important to have someone who is responsible for the maintenance of the machine and equipment in the language laboratory. A language laboratory manager or coordinator has to manage that job (Marzuki, 2014). There are two kinds of maintenance. They are preventive and curative maintenance. As preventive maintenance, teachers should train the learners how to use the equipment, identify the functions of each machine, and handle the tapes in correct ways. Learners should keep clean the headphone and microphone for hygienic purposes. There are certain devices are damaged easily if they get with dust. Curative maintenance means that teachers and learners should identify the equipment and machine which are not functioning properly, so that after the class they tell the language laboratory assistant to handle it. It aims to make sure that every minor or major fault is repaired without unnecessary delay (Yeong \& Chiew, 2014).

\subsubsection{Supporting System}

To keep the effort and enthusiasm of language laboratory users, there should be consistent encouragement and support from the administration (Krishna, 2021). There should not be complicated administration to use language laboratory room to conduct experiment. If administration of 
language laboratory usage is complex, it discourages teachers to use it. They will prefer teaching at traditional classroom to teaching at language laboratory. The principal as a policy maker should have good coordination with language laboratory manager to allow language laboratory users to use with high confidence. The principal is expected to enrich resources and make the facilities better for teaching and learning in language laboratory (Sihite, 2017).

An activity in a language laboratory cannot run properly because coordination and organisation systems are not implemented properly (Buska et al., 2020). Therefore, each party must carry out their main duties and functions so that the management of learning in the laboratory runs systematically. Activities that run systematically tend to produce effective results.

\section{Method}

This research aims to explore information provided by the English teachers from multiple Islamic schools in Majene, West Sulawesi, Indonesia, regarding the existence of English language laboratory at Islamic schools in the level of junior high school. The study uses a descriptive quantitative method, using questionnaires to collect data from the English teachers that represents each school.

The population of this study are twenty-four English teachers from twenty-four Islamic schools. Random sampling is used with Slovin's formula (Stephanie, 2003) with $10 \%$ margin errors, thus the representative samples in this study are 22 English teachers.

Table 1. List of Representative Islamic Schools and English Teachers

\begin{tabular}{lll}
\hline No & \multicolumn{1}{c}{ Islamic Schools } & English Teachers \\
\hline 1. & MTsS Guppi Mekkatta & NM \\
2. & MTsS DDI Totolisi & HS \\
3. & MTsN 2 Majene & SB \\
4. & MTsS PPTI Tamo & JM \\
5. & MTsS Guppi Pesuloang & SF \\
6. & MTsS Al-Qalam Teppo & SR \\
7. & MTsS DDI Lombo'na & WY \\
8. & MTsS BPII Pamboang & AF \\
9. & MTsN 1 Majene & EH \\
10. & MTsS DDI Seppong & NL \\
11. & MTsS Muhammadiyah Pelattoang & RW \\
12. & MTsS GUPPI Ulidang & AM \\
13. & MTsS DDI Baruga & ND \\
14. & MTsS Darul Hikmah Poniang & HW \\
15. & MTsS Guppi Majene & SR \\
\hline
\end{tabular}

\begin{tabular}{lll}
\hline 16. & MTsS DDI Banua & AB \\
17. & MTsS DDI Somba & ND \\
18. & MTsS Ijtihad Sambabo & PM \\
19. & MTsS DDI Taukong & AN \\
20. & MTsS Limboro Sendana & IB \\
21. & MTsS DDI Majene & BP \\
22. & MTsS DDI Malunda & SR \\
\hline
\end{tabular}

To gain information related to this research, the researchers used eight-item questionnaire which were given and completed at the end of 2019 and in the beginning of 2020. The data gained from the questionnaire were analysed by using per centage technique.

\section{Results}

After analysing the data regarding the existence of language laboratory in English learning at Islamic schools in Majene, West Sulawesi, overall results are displayed on Tables 2, 3 and 4.

Table 2. Existence of a Language Laboratory in Islamic School of Majene

\begin{tabular}{lllc}
\hline No & \multicolumn{1}{c}{ Questions } & Yes & No \\
\hline 1 & $\begin{array}{l}\text { Do you have a language laboratory } \\
\text { at your school? }\end{array}$ & $0 \%$ & $100 \%$ \\
2 & $\begin{array}{l}\text { According to you, is the language } \\
\text { lab important to support your } \\
\text { language practicum activities at } \\
\text { school? }\end{array}$ & $100 \%$ & $0 \%$ \\
3 & $\begin{array}{l}\text { Is there a budget for providing } \\
\text { language laboratory facilities at } \\
\text { your school? }\end{array}$ & $0 \%$ & $100 \%$ \\
$4 \quad \begin{array}{l}\text { Have you ever been assigned to } \\
\text { take part in a language lab training } \\
\text { course by your leader? }\end{array}$ & $0 \%$ & $100 \%$ \\
5 & $\begin{array}{l}\text { Is there a language laboratory } \\
\text { technician at your school? } \\
\text { Does your school have teaching } \\
\text { materials in the form of textbooks } \\
\text { equipped with audio cassettes or } \\
\text { CDs for language practicum? }\end{array}$ & $50 \%$ & $50 \%$ \\
\hline
\end{tabular}

Table 2 shows that all (100\%) English teachers from every 22 Islamic schools admit that their schools have no a language laboratory. Their schools only have regular classrooms that are not specialised to conduct English learning practicum. There is no technological instalment in a specific room which supports to manage effective interaction among students in learning a new language. Multimedia laboratories, conventional laboratories also do not exist. When the digital world has penetrated all aspects of life in this $21 \mathrm{st}$ century, the absence of language laboratory at schools is certainly concerning. 
All English teachers at Islamic School in Majene, West Sulawesi agree that the existence of language laboratory is very important to facilitate students to practice a second or foreign language learning. Their agreement shows that the provision of a language laboratory has become a necessity in learning foreign languages.

A hundred per cent English teachers affirm that none of their schools provides budget for language laboratory facilities. It indicates that the language laboratory is not priority for policy makers at schools. From many needs of schools, the procurement of this language laboratory has not been considered a priority. This can be seen from the budgeting carried out by policy makers in schools

All principals at Islamic schools also have never assigned their English teachers to join or to attend language laboratory training. It indicates that policy makers at school do not support professional development of English teachers in terms of the usage of language laboratory. The alignment of the policy makers for the development of the teacher's self-development in the field of language laboratories in schools has not been seen.

In addition, 100\% Islamic schools have no language laboratory technician. This shows that the school does not yet have human resources who are capable of managing a language laboratory. This also indicates that the recruitment of laboratory assistants or technicians in schools has not been considered important.

Nevertheless, there is some hope as 50\% Islamic schools have teaching materials in the form of textbooks equipped with audio cassettes or CDs for English learning practicum, even though an equal number of schools (50\%) do not. This shows that some English teachers in Islamic schools of Majene have preparations to carry out practical activities by using existing materials.

Table 3. The English Skill that is Rarely Practiced by Students

\begin{tabular}{|c|c|c|c|c|}
\hline No & Questions & & Choices & Per centages \\
\hline \multirow[t]{4}{*}{7} & \multirow{4}{*}{$\begin{array}{l}\text { From the four } \\
\text { English skills, } \\
\text { which skill is } \\
\text { rarely practiced } \\
\text { by students? }\end{array}$} & a. & Listening & $81.8 \%$ \\
\hline & & b. & Speaking & $16.6 \%$ \\
\hline & & c. & Reading & $0 \%$ \\
\hline & & d. & Writing & $1.6 \%$ \\
\hline
\end{tabular}

Table 3 presents that there are $81.8 \%$ English teachers at Islamic schools in Majene who seldom conduct practicum activities for listening skill; there are $16.6 \%$ who seldom have practicum activities for speaking; and there are 1.6\% English teachers who seldom practice writing with their students. All English teachers at Islamic schools in Majene often conduct practical works for reading skill. It implies that students at Islamic schools are familiar with reading activities than other skills. Listening skill becomes the skill that is most rarely practiced by students. Its portion is very low among others. This is relevant to what Amal et al say that EFL learners are not familiar with listening to native speaker sounds (Amal, 2019). It is because they rarely practice listening.

Table 4. Factors Affecting the Infrequent Practical Activities for the Under-used Skills

\begin{tabular}{lllll}
\hline No & Questions & & \multicolumn{1}{c}{ Choices } & Per centages \\
\hline 08 & $\begin{array}{l}\text { What is } \\
\text { the cause } \\
\text { of the lack } \\
\text { of } \\
\text { practical } \\
\text { activities } \\
\text { for that } \\
\text { skill? }\end{array}$ & a. & $\begin{array}{l}\text { Teachers have lack } \\
\text { of teaching materials } \\
\text { for that skill } \\
\text { Teachers do not } \\
\text { master the skill }\end{array}$ & $40.9 \%$ \\
& c. & $\begin{array}{l}\text { Teachers do not have } \\
\text { teaching media to } \\
\text { teach it }\end{array}$ & $59.1 \%$ \\
\hline
\end{tabular}

Table 4 shows the reasons why English teachers at Islamic schools may rarely accommodate their students to practice a certain English skill as indicated in Table 3. 40.9\% English teachers reasoned that they had lack of teaching materials for that skill. It implies that some English teachers at Islamic schools in Majene do not have listening, speaking or writing references for practical activities. The others of $59.1 \%$ English teachers make a reason that they did not have teaching media to teach it. It indicates that teachers have limitation on supporting media to provide practical activities for certain skills such as listening, speaking and writing.

For practical activities of the four types of language skills, teaching and learning media especially media from technology development and usage contributes to facilitate English learning practices. Technology offers ease for both teachers and students (Ahmadi, 2018). A modern language laboratory provides many kinds of media and facilities in which English teachers can design effective interaction in limited time to improve students' chance to practice the new languages that they learn. Therefore, the existence of language laboratory must be noticed.

\section{Discussion}

The current study results support the existence of language laboratory in English learning. There are three main categories as the main focuses to show language laboratory existence at Islamic schools as follow:

\subsection{Language Laboratory Facilities}

All the Islamic schools in Majene as the place for the study do not have a language laboratory. Even though schools have no language laboratory, most of the teachers believe that it is an important infrastructure to have at school. Furthermore, they do not have the facilities to carry out these activities. They carry out practical English activities, not in accordance with the criteria for actual practicum activities. In the system of Indonesia education, 
infrastructures and school facilities has standard. This is regulated in the Regulation of the Minister of National Education of the Republic of Indonesia Number 24 of 2007 (National Education Standards Agency, 2020). It is critical to construct educational infrastructure in such a way that the education offered is as accessible and effective as possible. The statements are replicated findings from Barret et al. (2019) regarding the belief that language laboratory facilities and infrastructure can support the achievement of students' learning outcomes.

Unlike the findings of Mulyaningsih (2019) regarding the existence of the language laboratory, she found in her research that vocational schools in Ogan Komering Ulu Palembang had good facilities. Unfortunately, the infrastructures of their language laboratories were poor. This totally had an impact on English activities which were not optimal at schools. In her research, she correlated the results of students' national examination scores to the facilities using Spearman Rank-Order Correlation Coefficient. She found that the infrastructures of language laboratory were quite influence students' learning outcomes (Mulyaningsih, 2019). That research emphasises that in the existence of a language laboratory totally support English activities at schools. Its facilities offered to school strengthen the students' performance. Thus, the provision of a language laboratory with modern facilities must be budgeted by the schools. In addition, the presence of human resources who are capable of managing language laboratories must also be a concern.

The presence of a language laboratory in Islamic schools does not only bring benefits for English but also Arabic as well. Islamic schools under Ministry of Religious Affairs (MORA) have that both foreign languages in the curriculum (Aslam, 2016). Optimisation of foreign language learning can be achieved when Islamic schools prepare adequate facilities for both teachers and students.

The importance of availability of learning facilities had been emphasised by Lebuan in his research. He found that instructional activities had significant and positive impact when teacher assessment and learning facilities are controlled (Lebuan, 2017). A language laboratory as one of supporting facility in language learning cannot be denied. If a school already has a proper space to be used as a language laboratory, then the school needs to consider procuring the completeness of the contents of a language laboratory such as master table, computer, etc.

In today's modern era, the provision of a language laboratory is not impossible. If a school has not been able to hold a multimedia-based language laboratory, a conventional-based or lingua-phone-based language laboratory can be attempted. The facilities needed by conventional and lingua phone language laboratory are not difficult to find. Furnitures such as tape recorders and headsets are easy to find at affordable prices. Language laboratory facilities is not only about hardware. It is also about software. Even a school has good quality of language laboratory hardware, but it is not equipped with adequate software, then the language laboratory cannot function optimally. Audio or video files that can optimize language learning are also as important as the procurement of language laboratory hardware.

However, the procurement of a language laboratory must also consider the number of seats provided in a language lab. If the seats provided are only able to accommodate half of the number of students, then what is expected cannot be achieved optimally (Al-Ameedi et al., 2019). The procurement of a language lab must be equipped with adequate facilities so that the lab can work according to its functions.

\subsection{Learning Activities}

The results above show that practical activities in language laboratories, especially in Islamic schools of Majene, are very passive. Teachers transfer knowledge and apply learning activities in the form of assignments only in regular class. The absence of schools' initiative to send English teachers to participate in language laboratory training makes teachers less competent to prepare themselves to manage language learning in language laboratories in the future. These kinds of conditions have a negative impact on language learning at schools. This finding is distinctly different from Mulyaningsih's (2019) who emphasized that the language laboratory facilities and infrastructure in vocational schools had a sufficient influence on student learning achievement. It is also found that the results of this research contrasts to the findings of Obiageli \& Ogochukwu (2017), who revealed the importance of the language laboratory for English learning. They identified the importance of the language laboratory for English learning, emphasising that language laboratory is best used for teaching speaking in which students fully participate in speaking and interacting with their partners. Unfortunately, Islamic schools in Majene do not have such facility, thus problems related to lack of participation for practical activities are still happening.

Due to the absence of a language laboratory at Islamic schools of Majene, there is no high participation in learning activities which trains students' speaking skills; There are only speaking learning activities with limited participation. It can be said that the existence of a language laboratory greatly affects the level of student participation in practice speaking English. Learning speaking is closely related to listening learning. If students do not have good listening skills, then it will affect their speaking skills (Tuan \& Mai, 2015). Therefore, listening practice activities should be intensified. The absence of this language laboratory becomes a factor that affects the rare implementation of listening practice activities at Islamic schools of Majene. This also automatically has an impact of lack of input that affects the low language production.

Playing audio or video and providing texts in language laboratory increase language input for students. It leads to 
language acquisition for them. Nevertheless, a bunch of input without sufficient interaction by students will not lead to language acquisition (Maharsi, 2016). Giving language input and promoting interaction can be done by teachers in the regular classroom, but assistance of advance technological tools in a language laboratory can make it more effective and efficient.

\subsection{School Policy for Language Laboratory Existence}

The current study also extends the finding of the literature by identifying the urgent of the language laboratory for improvement in English skills. This can be identified from what the English teachers of Islamic schools in Majene believe that the existence of language laboratory is urgent for students' improvement in English skills. Limited facilities and infrastructure make the English teachers powerless to carry out practice activities. Unfortunately, this belief is not supported by the availability of a budget for procurement of language laboratories by school policy makers.

School finances must be managed wisely which is consistent with the findings by Mosala \& Mofolo (2016). The school must be selective to determine the priority needs of the school, so that they can use the budget wisely and can support the effectiveness of learning in schools. Budget allocations made in schools reflect the priority level of policy makers there. If the language lab has not been provided so far, it could be because the language lab is not considered a priority to be provided. This view needs to be changed if schools think that students' English language skill is a soft skill which is very important for them to develop at this time.

If policy makers have no sufficient budget for providing a representative language laboratory at a school, Headmaster and English teachers may take an initiative to allow students bring their own devices. Teachers may apply Mobil Assisted Language Learning (MALL) approach, in which students are allowed to bring portable technology devices to language classes. Mobile technological devices such as laptops, smart phones, tablets, etc has computing power (Sung et al., 2016). It brings great potential in language classrooms.

Those mobile devices that are used daily can be optimised for their function in learning and teaching. The trend of using technology equipment in learning is also growing faster since it is very close to the students' preference and interest (Hafizah \& Nur-Ehsan, 2020). Students even admit that technology ease their life (Dağhan, 2017). Sophisticated features that are built into the devices have the same functions as some language laboratory equipment, such as recording device, radio, and video player. Additional software that can be downloaded in App store of Playstore is able to maximise the functions.
Mobile learning creates a learning environment with a high level of participation by using various applications provided in the mobile devices (Bachore, 2015). Lam in Kuimova (2018) argued that Mobile learning is interactive and flexible. It includes a number of such as watching, listening, reading and writing (Kuimova et al., 2018). Those activities are almost similar to what is offered by a language laboratory.

This great potential has to be considered by the English teachers. The absence of a language laboratory is not a dead end in language learning. Nowadays we are living side by side with technological advances. It brings a bunch of advantages for language learning. It, however, do not guarantee give automatic positive effects. It depends on how teachers manage it (Ahmadi, 2018). Therefore, English teachers have to be agile and responsive to the barriers faced in the midst of existing limitations.

In addition to the many benefits offered by the use of mobile devices by students themselves, there are also a number of disadvantages. Students are sometimes unable to distinguish the use of these tools for learning purposes or for personal use (Cojocnean, 2017). Therefore, teachers play a big role to make learning effective with the use of mobile technology devices. Its usage of has to get agreement from Headmaster as the policy makers at school.

\section{Conclusion}

This study found that all English teachers representing 22 Islamic schools in Majene agree that a language laboratory is essential for language practicum activities; however, they have had to accept the fact that their schools is not equipped with a language laboratory. This study revealed that these English teachers in Islamic schools conduct practice activities in the classroom with multiple levels of limitations due to the fact that policy makers at schools do not prioritise the language laboratory and its facilities, do not budget it in the school financial planning, do not prepare human resource to be language laboratory users (teachers as facilitators) and do not assign or encourage teachers to join language laboratory trainings or seminars.

Several schools even do not have teaching materials and media for practice activities especially for listening, speaking and writing skills, significantly dampening the optimisation of the English teachers' language teaching process. However, English teachers are able to take other alternatives to optimise practice activities in the middle of the absence of a language laboratory at school. They may use mobile assisted language learning approach. They can create a similar language laboratory situation with mobile technology tools brought by students themselves.

This study contributes to the under-exploration of language laboratories in a large number of a unique type of school, illuminating several existing issues in Islamic schools. However, this investigation only covers the surface 
information, relying on data given by one English teacher from each school. Future studies are highly recommended to explore how policy makers in both Ministry of Religious Affairs and policy makers at school level can provide budget for the procurement of language laboratory and its facilities in Islamic schools of Majene.

\section{References}

Abdelaziz, M. (2017). The Role of Language Laboratory in English Language Learning Settings. English Language Teaching, 10(2). https://doi.org/http://dx.doi.org/10.5539/elt.v10n2p86

Abdulla, M. D., \& Kumar, A. (2017). Multi-media language lab: A four walled room to groom the communicative competence of engineering graduates. International Journal of Applied Research, 3(2), 6871.

Adamu, A., \& Umar, M. M. (2018). The Roles of the LanguageLaboratory inTeaching Languages: A Case Study of Bayero University, Kano. International Journal of Humanities and Social Science Invention (IJHSSI), 7(6), 29-40.

Ahmadi, D. M. R. (2018). The Use of Technology in English Language Learning: A Literature Review. International Journal of Research in English Education, 3(2), 115-125. https://doi.org/10.29252/ijree.3.2.115

Al-Ameedi, R. T., Ibrahim, E. R., \& Nayef, K. J. (2019). Language Laboratory and Developing Skills in An Iraqi Secondary School. Journal of Southwest Jiatong University, 54(5), 387-392. https://doi.org/10.35741/issn.0258-2724.54.5.46

Alkhaldi, T., Pranata, I., \& Athauda, R. I. (2016). A Review of Contemporary Virtual and Remote Laboratory Implementations: Observations and Findings. Journal of Computers in Education, 3(3), 329-351. https://doi.org/10.1007/s40692-016-0068-z

Allen, J. R. (1974). The Case Against the Conventional Language Laboratory. System, 2(1), 10-13. https://doi.org/10.1016/0346-251X(74)90017-7

Amal, et all. (2019). Using English Movie with Delay and Non Delay Subtitle to Improve Listening Skill. Journal of Linguistics and English Teaching Studies, 1(1), 1-10.

Aslam, M. (2016). Foreign Language Curriculum. In Tesis. UIN Sunan Kalijaga.

Asningtias, S. (2018). Utilizing Language Laboratories: Chances and Challenges in Teacherrs Perspective. Advance in Social Science, Education and Humanities Research, 222(April), 198-200. https://doi.org/10.2991/soshec-18.2018.43

Asri, A. N., Syaifudin, Y. W., \& Rozi, I. F. (2016).
Effective Digital Laboratory for English Language Teaching. Proceeding of International Conference on Language, Literary and Cultural Studies (ICON LATERALS), October 2016, 116-128. https://doi.org/10.21776/ub.icon

Aulia, V. (2016). Language Laboratory Management To Support Technology-Based Foreign Language Instruction. JEELS (Journal of English Education and Linguistics Studies), 3(2), 181-196. https://doi.org/10.30762/jeels.v3i2.212

Bachore, M. M. (2015). Language Learning through Mobile Technologies: An Opportunity for Language Learners and Teachers. Journal of Education and Practice, 6(31), 50-53.

Barrett, P., Treves, A., Shmis, T., Ambasz, D., \& Ustinova, M. (2019). The Impact of School Infrastructure on Learning: A Synthesis of the Evidence. In The Impact of School Infrastructure on Learning: A Synthesis of the Evidence. https://doi.org/10.1596/978-1-4648$1378-8$

Barson, J; Debski, R. (1996). Calling back CALL: technology in the service of foreign language learning based on creativity, contingency, and goaloriented activity. University of Hawaii, Second Language Teaching and Curriculum Center.

Blanco-Elorrieta, E., \& Pylkkänen, L. (2017). Bilingual language switching in the laboratory versus in the wild: The spatiotemporal dynamics of adaptive language control. Journal of Neuroscience. https://doi.org/10.1523/JNEUROSCI.0553-17.2017

Borges, V. M. C. (2014). Are ESL/EFL Software Programs Effective for Language Learning? Ilha Do Desterro, 66, 19-74. https://doi.org/10.5007/21758026.2014n66p19

Borowska, A., \& Enright, A. (2015). Changing Perspectives on Aviation English Training. In International Civil Aviation English Association.

Bosco, T. J., Gabriel, B., Florence, M., \& Gilbert, N. (2020). Towards effective Teaching and learning ESP in mixed classes: Students' interest, challenges and remedies. International Journal of English Literature and Social Sciences. https://doi.org/10.22161/ijels.52.27

Buska, W., Latif, M., Risnita, R., Us, K. A., \& Prihartini, Y. (2020). The Management of Language Laboratory in Improving Students Arabic Competence. Arabi: Journal of Arabic Studies, 5(1), 51. https://doi.org/10.24865/ajas.v5i1.249

Cesteros, A. F.-P. (2014). What is language laboratory? Roycan.

Chandradasa and Jayawardane. (2018). The Role of the Language Laboratory in Learning English as a 
Second Language in a University Context with Reference to Sri Lanka. People: International Journal of Social Sciences, 4(1). https://doi.org/https://dx.doi.org/10.20319/pijss.2018. 41.133152

Cojocnean, D. (2017). Mobile Learning in the Foreign Language Classroom - Challenges and Opportunities. Revista de Pedagogie - Journal of Pedagogy, LXV(1), 59-72. https://doi.org/10.26755/revped/2017.1/59

Cosmas, A. F. (2020). Assessment of Language Laboratory and Teaching and Learning of English Language Pronunciation among Undergraduate Students in Nigerian Tertiary Institutions. Middle European Scientific Bulletin, 5(October), 33-37.

Dağhan, G. (2017). Views of Students about Technology, Effects of Technology on Daily Living and Their Professional Preferences. Turkish Online Journal of Educational Technology, 16(4), 187-194.

Deepika, \& Kalairasan. (2012). The Role of Language Lab in Learning English as A Second Language. Journal of Technology for ELT, 2(1).

Desi. (2006). Unterricht und Kompetenzerwerb in Deutsch und Englisch. In Deutsches Institut für Internationale Pädagogische Forschung [DIPF].

Ermawati, \& Umar, U. (2020). Factors Affecting the Use of ICT in Learning Environment: Teachers' Perspectives. The 2nd International Conference on English Language Teaching (ICONELE) 2020, 122130.

Evan, M. (2009). Foreign Language Learning with Digital Technology. Education and Digital Technology. Continuum International Publishing Group.

Hafizah, M. K., \& Nur-Ehsan, M. S. (2020). Education and Social Sciences Review The integration of mobile learning among ESL teachers to enhance vocabulary learning. Education and Social Sciences Review, 1(2), $28-36$.

Joan, P. (2016). The Influence of Language Laboratory in the Academic Achievement of Students in French. European Journal of Language Studies, 3(2), 75-80.

Kampushaen, D. (2013). Past, Present, and Future: From Traditional Language Laboratories to Digital Language Laboratories and Multimedia ICT Suites. The Tenth International Conference on ELearning for Knowledge-Based Society.

Kemenag, P. (2014). Madrasah lebih baik, lebih baik madrasah. Dirjen Pendis Kemenag RI.

Khaleel, M. S. (2020). Language Laboratory (Issue July) [University of https://doi.org/10.13140/RG.2.2.21635.12321

Khalil, N. M., \& Ibnian, S. S. (2020). The Use of Language
Laboratory in TEFL from University Students , Perspective. European Journal of Scientific Research, 156(4), 402-414.

Kin-Sys. (2007). Solutions Private Limited. Kin-Sys.

Krishna, D. (2021). Importance of Language Laboratory in Developing Language Skills. Jurnal Arbitrer, 8(1), 101. https://doi.org/10.25077/ar.8.1.101-106.2021

Kuimova, M., Burleigh, D., Uzunboylu, H., \& Bazhenov, R. (2018). Positive effects of mobile learning on foreign language learning. TEM Journal, 7(4), 837841. https://doi.org/10.18421/TEM74-22

Kumar, A. (2017). Multi-Media Language Lab: A Four Walled Room to Groom the Communicative Competence of Engineering Graduates. International Journal of Applied Research, 3(2), 68-71.

Kurniawa, I. (2014). Problematika Penggunaan Laboratorium Bahasa (Studi Kasus di MAN Model Bandar lampung). Engedu, 6(1).

Lebuan, A. P. (2017). Learning Facilities, Instructional Activities and Teacher Assessments' Effects on Students' English Achievement. Lingtera, 4(2), 197208. https://doi.org/10.21831/lt.v4i2.17093

Maharsi, I. (2016). The Importance of Input and Interaction in Second Language Acquisition. Journal of English and Education, 5(1), 45-53. https://doi.org/10.20885/jee.vol5.iss1.art4

Marzuki, M. (2014). Managing an Effective English Language Laboratory in a Polytechnic. Studies in English Language and Education, 1(2), 108. https://doi.org/10.24815/siele.v1i2.1830

Matthew, F. A. (2020). The Influence of Standard Language Laboratory on the Effective Teaching and Learning of English Language. Language in Indi, 20(7), 164-180.

Mercy, M. (2016). Effectiveness of Using Language Laboratory in Teaching English Amng Vii Standard Students in Coimbatore District. International Journal of Research-Granthaalayah, 4(5).

Mosala, G., \& Mofolo, M. A. (2016). Effective use of Budgeting as a Tool Towards Financial Management in Schools in Lejweleputswa District. Africa's Public Service Delivery and Performance Review, 4(3), 389. https://doi.org/10.4102/apsdpr.v4i3.121

Mulyaningsih, R. (2019). The Relationship Between School Facility and Infrastructure and the English Achievement of Students in Vocational School in Ogan Komering Ulu. Sriwijaya University.

National Education Standards Agency. (2020). Facilities and Infrastructure Standards. National Education Standards Agency.

Navas, B. (2013). The Language Laboratory and the Efl 
Course. IOSR Journal of Humanities And Social Science (IOSR-JHSS), 6(1), 8-14.

Nonci, J., Sulviana, \& Abdullah. (2018). The Utilization of Multimedia Language Laboratory in English Learning. International Journal of Linguistics and Humanities, 1(1), 16-25.

Obiageli, E. H., \& Ogochukwu, E. D. (2017). International Digital Organization for Scientific Research IDOSR Journals of Arts and Management. Idosr Journal of Science and Technology, 2(2), 99-116.

Patel, C. (2013). Use of Multimedia Technology in Teaching and Learning Communication Skill: An Analysis. International Journal of Advancements in Research \& Technology, 2(7).

Permendiknas No 41. (2007). Process Standard for Secondary Schools.

Rao and Velagala. (2016). Functions and Major Problems Faced in Language Laboratories. BEST: International Journal of Humanities, Arts, Medicine and Sciences (BEST: IJHAMS), 4(7).

Sahraini, \& Syamsudarni. (2018). Helping islamic higher education students learn listening skills by using video-cast. Asian ESP Journal.

Sihite, J. (2017). The Role of Language Lab Technique in Learning English ( Listening and Laboratory Work Analysis ).

Stack, E. . (1971). The language laboratory and modern language teaching. Oxford University Press.

Stephanie, E. (2003). Slovin's Formula Sampling Techniques. Houghton-Mifflin.

Sung, Y. T., Chang, K. E., \& Liu, T. C. (2016). The effects of integrating mobile devices with teaching and learning on students' learning performance: A metaanalysis and research synthesis. Computers and Education, 94, 252-275. https://doi.org/10.1016/j.compedu.2015.11.008

Tuan, N. H., \& Mai, T. N. (2015). Factors Affecting Students' Speaking Performance at Le Thanh Hien high school. Asian Journal of Educaitonal Research, $3(2), 8-23$.

Vishalakshi. (2011). Significance of Language Laboratory in Learning English as a Second Language. Indian Journal of Applied Research, 4(5), 162. https://doi.org/10.15373/2249555x/may2014/50

Warschauer, M. (1996). Computer Assisted Language Learning: an Introduction. Logos International.

Yeong \& Chiew. (2014). Effective Utilization of A Language Laboratory. Teaching and Learning. Institute of Education (Singapore), 1(2), 77-89.

Zaim, M. (2017). Implementing Scientific Approach to
Teach English at Senior High School in Indonesia. Asian Social Science. https://doi.org/10.5539/ass.v13n2p33 